https://doi.org/10.15255/KUI.2020.016

\title{
High Yield Dihydroxystearic Acid (DHSA) Based on Kinetic Model from Epoxidized Palm Oil
}

\author{
M. J. Jalil,a, K. A. Kamal, ${ }^{a}$ A. F. B. M. Yamin, ${ }^{a}$ I. S. Azmi, ${ }^{\text {b }}$ \\ M. H. Hassan, ${ }^{a}$ A. R. Hidayu, and K. N. Ismailc \\ a Faculty of Chemical Engineering, Universiti Teknologi MARA Cawangan Pulau Pinang, \\ Kampus Permatang Puah, 13500 Permatang Pauh, Pulau Pinang \\ ${ }^{b}$ Faculty of Chemical Engineering, Universiti Teknologi Mara Cawangan Johor Kampus Pasir \\ Gudang, 81750 Masai, Johor \\ 'Faculty of Chemical Engineering, Universiti Teknologi MARA, 40450 Shah Alam, Selangor
}

\begin{abstract}
In recent years, studies related to the epoxidation of fatty acids have garnered much interest due to the rising demand for eco-friendly epoxides derived from vegetable oils. From the epoxidation reaction, there is a side reaction involving epoxide and water. This reaction produces a by-product - dihydroxystearic acid $\left(\mathrm{C}_{18} \mathrm{H}_{36} \mathrm{O}_{4}, \mathrm{DHSA}\right)$. DHSA is one of the chemical precursors in the production of cosmetic products. Therefore, a kinetic model was developed to determine the optimised epoxidation process and concentration of DHSA, where each of the reactions was identified. The kinetic rate, $k$ parameters obtained were: $k_{11}=6.6442, k_{12}=11.0185, k_{21}=0.1026$ for epoxidation palm oleic acid, and $k_{41}=0.0021, k_{51}=0.0142$ in degradation process. The minimum error of the simulation was 0.0937. In addition, DHSA yield optimisation was done through Taguchi method, and the optimum conditions obtained were $\mathrm{H}_{2} \mathrm{O}_{2}$ /oleic acid - OA unsaturation molar ratio $1: 1$ (level 2), formic acid - FA/OA unsaturation molar ratio 0.5 : 1 (level 1), temperature $35{ }^{\circ} \mathrm{C}$ (level 1), and agitation speed $100 \mathrm{rpm}$ (level 1). A high yield of DHSA can be achieved under these conditions.
\end{abstract}

\section{Keywords}

Epoxidation, kinetic rate, MATLAB, DHSA, Taguchi

\section{Introduction}

The growth in vegetable oil demand has increased compared to the petroleum-based polymer. ${ }^{1}$ Since petroleum causes environmental pollution concerns, vegetable oil has become an alternative in the production of the epoxide. In the epoxidation reaction of vegetable oil, oxirane ring-opening, known as epoxide ring degradation, will occur. ${ }^{2}$ The oxirane ring-opening depletes the yield and can cause high peroxide values of epoxidized vegetable oils, so the opening needs to be minimised. ${ }^{3}$ The commercial production of palm oil is quite high compared to that of other vegetable oils. ${ }^{4}$ The low cost of palm oil makes studies on the synthesis and oxirane cleavage of palm oil more practical and economical. ${ }^{5}$ Epoxidized palm oil (EPO) can be obtained by reacting to the double bond of oil with peroxy acid that is generated in situ by reacting with concentrated hydrogen peroxide $\left(\mathrm{H}_{2} \mathrm{O}_{2}\right)$ and formic acid $\left(\mathrm{CH}_{2} \mathrm{O}_{2}, \mathrm{FA}\right)$ in the presence of mineral salt as a catalyst. ${ }^{2}$ The EPO can be used as a raw material in the manufacture of a wide range of products, such as paint, plastic, and adhesives. Besides, EPO is obtained from renewable resources, and can be regarded as biodegradable and non-toxic. Hence, it is suitable in replacing petroleum, since petroleum is toxic and harmful to the environment.

In this study, the oxirane-ring degradation of epoxidation palm oil was determined through MATLAB simulation. Ode45 is one of the tools in MATLAB designed to work with differential equations. The benefit of this tool is its ability to determine the reaction rate of the epoxidation and degradation of EPO. Nevertheless, the epoxy that reacts with water produces DHSA. The physical appearance of DHSA is white and tasteless with an acid odour, and is non-irritating to the skin. ${ }^{6}$ It is suitable for cosmetic ingredients. As the cosmetic industry is gradually increasing, it is suitable to produce a large amount of DHSA. ${ }^{7}$ However, literature on the optimisation of DHSA production is still lacking and has only a few references. Thus, in this paper, the optimisation of DHSA production will be studied by the Taguchi method, and by referring the data from the simulation.

\section{Methodology}

\subsection{Kinetic model}

Two main reactions involved in epoxidation of palm oil can be illustrated in Eqs. 1 and 2, while, the degradation of epoxidation is described in Eqs. 3, 4, and 5.

$$
\begin{gathered}
\mathrm{FA}+\mathrm{H}_{2} \mathrm{O}_{2} \underset{k 12}{\stackrel{k 11}{\rightleftarrows}} \mathrm{PFA}+\mathrm{H}_{2} \mathrm{O} \\
\mathrm{PFA}+\mathrm{OA} \stackrel{k 21}{\rightarrow} \mathrm{EPOXY}+\mathrm{FA} \\
\mathrm{EPOXY}+\mathrm{H}_{2} \mathrm{O} \stackrel{k 31}{\rightarrow} \mathrm{DHSA} \\
\mathrm{EPOXY}+\mathrm{H}_{2} \mathrm{O}_{2} \stackrel{k 41}{\rightarrow} \text { DEG1 } \\
\text { EPOXY }+\mathrm{FA}^{k 51} \rightarrow \text { DEG2 }
\end{gathered}
$$


where FA, $\mathrm{H}_{2} \mathrm{O}_{2}, \mathrm{PFA}, \mathrm{H}_{2} \mathrm{O}, \mathrm{OA}$, EPOXY, and DHSA are formic acid, hydrogen peroxide, performic acid, water, oleic acid, epoxide vegetable oil, and dihydroxystearic acid, respectively. From the given epoxidation and degradation process, the differential equations that describe each species are further derived as follows:

$$
\begin{aligned}
\frac{d[\mathrm{FA}]}{\mathrm{d} t}= & -k_{11}[\mathrm{FA}]\left[\mathrm{H}_{2} \mathrm{O}_{2}\right]+k_{12}[\mathrm{PFA}]\left[\mathrm{H}_{2} \mathrm{O}\right]+i_{21} \\
& +k_{21}[\mathrm{PFA}][\mathrm{OA}]-k_{22}[\mathrm{EPOXY}][\mathrm{FA}]- \\
& -k_{51}[\mathrm{EPOXY}][\mathrm{FA}]+k_{52}[\mathrm{DEG} 2] \\
\frac{d\left[\mathrm{H}_{2} \mathrm{O}_{2}\right]}{\mathrm{d} t}= & -k_{11}[\mathrm{FA}]\left[\mathrm{H}_{2} \mathrm{O}_{2}\right]+k_{12}[\mathrm{PFA}]\left[\mathrm{H}_{2} \mathrm{O}\right]- \\
& -k_{41}[\mathrm{EPOXY}]\left[\mathrm{H}_{2} \mathrm{O}_{2}\right]+k_{42}[\mathrm{DEG} 2] \\
\frac{d[\mathrm{PFA}]}{\mathrm{d} t}= & k_{11}[\mathrm{FA}]\left[\mathrm{H}_{2} \mathrm{O}_{2}\right]-k_{12}[\mathrm{PFA}]\left[\mathrm{H}_{2} \mathrm{O}\right]- \\
& -k_{21}[\mathrm{PFA}][\mathrm{OA}]+k_{22}[\mathrm{EPOXY}][\mathrm{FA}] \\
\frac{d\left[\mathrm{H}_{2} \mathrm{O}\right]}{\mathrm{d} t}= & k_{11}[\mathrm{FA}]\left[\mathrm{H}_{2} \mathrm{O}_{2}\right]-k_{12}[\mathrm{PFA}]\left[\mathrm{H}_{2} \mathrm{O}\right]- \\
& -k_{31}\left[\mathrm{H} \mathrm{H}_{2} \mathrm{O}\right][\mathrm{EPOXY}]+k_{32}[\mathrm{DHSA}] \\
\frac{d[\mathrm{OA}]}{\mathrm{d} t}= & -k_{21}[\mathrm{PFA}][\mathrm{OA}]+k_{22}[\mathrm{EPOXY}][\mathrm{FA}] \\
\frac{d[\mathrm{EPOXY}]}{\mathrm{d} t}= & k_{21}[\mathrm{PFA}][\mathrm{OA}]-k_{22}[\mathrm{EPOXY}][\mathrm{FA}]-{ }_{31} \\
& -k_{31}[\mathrm{EPOXY}]\left[\mathrm{H}_{2} \mathrm{O}\right]+k_{32}[\mathrm{EPOXY}]\left[\mathrm{H}_{2} \mathrm{O}\right] \\
\frac{d[\mathrm{DHSA}]}{\mathrm{d} t}= & k_{31}[\mathrm{EPOXY}]\left[\mathrm{H}_{2} \mathrm{O}\right]-k_{32}[\mathrm{DHSA}] \\
\frac{d[\mathrm{DEG} 1]}{\mathrm{d} t}= & k_{41}[\mathrm{EPOXY}]\left[\mathrm{H}_{2} \mathrm{O}_{2}\right]-k_{42}[\mathrm{DEG}] \\
& =k_{51}[\mathrm{EPOXY}][\mathrm{FA}]-k_{52}[\mathrm{DEG}] \\
&
\end{aligned}
$$

To determine the rate coefficient numerically, parametric studies were conducted. There were two computing processes involved, which solved a set of differential equations (Eqs. 6-14) numerically, and computed the errors between the experimental and the simulation. The Ode45 function of MATLAB was used to solve the differential equation by numerical integration using the fourth-order Runge-Kutta method. The parameter values were predicted using a genetic algorithm in MATLAB software. The algorithm can search for the optimal value of the process variable. ${ }^{8}$ The reliability of the parameters was verified by minimising the error, e, between the experiment and the simulation, as shown in Fig. 1.

\subsection{Optimisation procedure}

In recent research, the design of experiment (DOE) had been applied by implementing the Taguchi method ap-

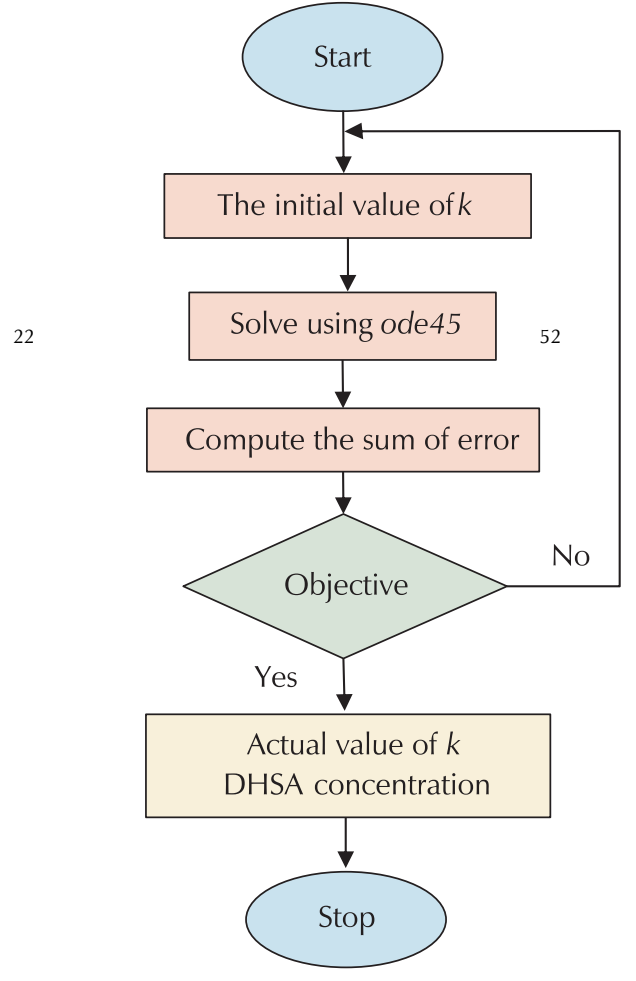

Fig. 1 - Determining reaction rate constant and optimisation of DHSA

proach. The method was developed by Taguchi and Kinoshi sto enhance the process parameters and increase the quality of components that were industrial. ${ }^{9}$ This method employs a set of orthogonal arrays; with reaction parameters, optimisation is performed using the lowest possible number of experimental runs..$^{10} \mathrm{~A}$ few parameters, such as reaction temperature, FA to OA unsaturation molar ratio, $\mathrm{H}_{2} \mathrm{O}_{2}$ to $\mathrm{OA}$ unsaturation molar ratio, and agitation speed can affect the reaction of epoxidation. All these parameters were explored with the diversity of levels, as shown in Table 1. Therefore, the optimal reaction conditions of these vital reaction temperatures were analysed based on a DOE approach. The diversity of factors was studied by crossing the orthogonal array of the control parameters. The result obtained was further analysed manually using the signal to noise $(\mathrm{S} / \mathrm{N})$ ratio and analysis of variance (ANOVA). The optimum combination of reaction conditions projected by the Taguchi method was then tested and validated by running a confirmation reaction at the optimal predicted reaction conditions.

Table 1 - Design of experiment (DOE) using four parameters and three levels

\begin{tabular}{c|c|c|c|c}
\hline \multicolumn{2}{c|}{ Parameters } & \multicolumn{3}{c}{ Levels } \\
\cline { 2 - 5 } \multicolumn{2}{c|}{} & 1 & 2 & 3 \\
\hline A & $\mathrm{H}_{2} \mathrm{O}_{2} / \mathrm{OA}$ unsaturation molar ratio & 0.5 & 1 & 1.5 \\
\hline B & $\mathrm{FA} / \mathrm{OA}$ unsaturation molar ratio & 0.5 & 1 & 1.5 \\
\hline C & Temperature $/{ }^{\circ} \mathrm{C}$ & 35 & 55 & 75 \\
\hline D & Agitation speed $/ \mathrm{rpm}$ & 100 & 200 & 300 \\
\hline
\end{tabular}


Choosing the parameters was conducted according to the suggestion given by $D$. B. Wijayasekara. ${ }^{11}$ For instance, $100 \mathrm{rpm}, 200 \mathrm{rpm}$, and $300 \mathrm{rpm}$ were the agitation speeds tested. The reaction temperatures $\left(35,55,75^{\circ} \mathrm{C}\right)$ were the reaction parameters, unsaturation molar ratio $(0.5,1.0$, 1.5) of $\mathrm{FA}$ to $\mathrm{OA}$, and unsaturation molar ratio $(0.5,1.0$, 1.5) of $\mathrm{H}_{2} \mathrm{O}_{2}$ to $\mathrm{OA}$, as shown in Table 1. Optimisation was conducted using the analytical Taguchi method to find the optimum conditions for every parameter.

\section{Results and discussion}

\subsection{Reaction rate of DHSA production}

Kinetic model for catalytic epoxidation of palm oleic acid based on palm oil (PO) was developed by MATLAB simulation. The kinetic data for the epoxidation and degradation of palm oil corresponded to the initial concentration. The Genetic Algorithm (GA) method was used to fit the experimental data and the Runge-Kutta fourth-order method was applied using the Ode45 tool to solve the system of differential equations. There were 27 experiments run in the simulation, in order to ensure the optimal value of epoxidation. The experimental data was obtained from the previous experiments, and the simulation was based on that data. The initial concentration of formic acid (FA), hydrogen peroxide $\left(\mathrm{H}_{2} \mathrm{O}_{2}\right)$, and oleic acid (OA) from previous experimental data was chosen as a reference to find the kinetic rate constant, $k$. On the other hand, the kinetic rate was used to determine the concentration of DHSA in oxirane cleavage. This occurred when the epoxide reacted with water. It corresponded to the objective of this study.

From the 27 experiments that were run (Table 2), experiment 11 was chosen as the best to display the optimised epoxidation process, as it had the lowest error $(0.0937 \%)$ compared to others. The reaction rate constants for this experiment were: $k_{11}=6.6442 \mathrm{~mol} \mathrm{I}^{-1} \mathrm{~min}^{-1}$, $k_{12}=11.0185 \mathrm{moll}^{-1} \mathrm{~min}^{-1}, k_{21}=0.1026 \mathrm{moll}^{-1} \mathrm{~min}^{-1}$,

Table 2 - Simulation data

\begin{tabular}{|c|c|c|c|c|c|c|c|c|c|c|c|}
\hline \multirow{2}{*}{ Exp } & \multicolumn{3}{|c|}{ Initial concentration $/ \mathrm{mol}^{-1}$} & \multirow{2}{*}{$\begin{array}{c}k_{11} / \\
\mathrm{moll}^{-1} \min ^{-1}\end{array}$} & \multirow{2}{*}{$\begin{array}{c}k_{12} / \\
\mathrm{moll}^{-1} \min ^{-1}\end{array}$} & \multirow{2}{*}{$\begin{array}{c}k_{21} / \\
\mathrm{moll}^{-1} \min ^{-1}\end{array}$} & \multirow{2}{*}{$\begin{array}{c}k_{31} / \\
\operatorname{moll}^{-1} \min ^{-1}\end{array}$} & \multirow{2}{*}{$\begin{array}{c}k_{41} / \\
\mathrm{moll}^{-1} \min ^{-1}\end{array}$} & \multirow{2}{*}{$\begin{array}{c}k_{51} / \\
\mathrm{moll}^{-1} \mathrm{~min}^{-1}\end{array}$} & \multirow{2}{*}{$\begin{array}{l}\text { Error } \\
\min \end{array}$} & \multirow{2}{*}{$\begin{array}{c}\text { DHSA } \\
\text { estimated } \\
\text { concentration } \\
/ \text { moll }^{-1}\end{array}$} \\
\hline & $\mathrm{H}_{2} \mathrm{O}_{2}$ & FA & $A$ & & & & & & & & \\
\hline 1 & 1.4714 & 1.4714 & 9484 & 0.1174 & 0 & 0.0633 & 0.0135 & 0 & 0.0142 & 0.2945 & 0.733307 \\
\hline 2 & 1.4714 & 1.4714 & 2.9484 & 0.1028 & 0 & 0.0470 & 0.0136 & 0 & 0.0166 & 0.2694 & 0.700095 \\
\hline 3 & .4714 & 1.4714 & 2.9484 & 0.0543 & 0 & 8.5916 & 0.0283 & 0 & 0.0074 & .2892 & 1.017948 \\
\hline 4 & 1.4714 & 2.9484 & 2.9484 & 6.0964 & 1.2061 & 0.0239 & 0.0094 & 0.0242 & 0.0131 & 0.1500 & 0.404717 \\
\hline 5 & 1.4714 & 2.9484 & 2.9484 & 1.5720 & 1.9932 & 0.1575 & 0.0124 & 0 & 0.0075 & 0.3069 & 0.62633 \\
\hline 6 & 1.4714 & 2.9484 & 2.9484 & 0.0691 & 0 & 0.1030 & 0.0100 & 0 & 0.0101 & 0.1412 & 0.482747 \\
\hline 7 & 1.4714 & 4.4226 & 2.9484 & 0.0391 & 0 & 0.0967 & 0.0105 & 0 & 0.0068 & 0.1525 & 0.467893 \\
\hline 8 & 1.4714 & 4.4226 & 2.9484 & 0.0299 & 0 & 0.0638 & 0.0077 & 0 & 0.005 & 0.2158 & 0.469234 \\
\hline 9 & 1.4714 & 4.4226 & 2.9484 & 0.0477 & 0 & 0.1153 & 0.0078 & 0 & 0.0078 & 0.2258 & 0.360169 \\
\hline 10 & 2.9484 & 1.4714 & 2.9484 & 6.4757 & 10.7925 & 0.0583 & 0.0171 & 0.0041 & 0.0161 & 0.1815 & 1.583085 \\
\hline 11 & 2.9484 & 1.4714 & 2.9484 & 6.6442 & 11.0185 & 0.1026 & 0.0238 & 0.0021 & 0.0142 & 0.0937 & 1.954907 \\
\hline 12 & 2.9484 & 1.4714 & 2.9484 & 12.8848 & 0 & 0.0251 & 0.0122 & 0 & 0.1811 & 0.1136 & 1.603342 \\
\hline 13 & 2.9484 & 2.9484 & 2.9484 & 0.0486 & 0 & 0.0817 & 0.0168 & 0 & 0.0139 & 0.3010 & 1.592831 \\
\hline 14 & 2.9484 & 2.9484 & 2.9484 & 0.0227 & 0 & 11.9431 & 0.0196 & 0 & 0.0058 & 0.1978 & 1.941024 \\
\hline 15 & 2.9484 & 2.9484 & 2.9484 & 0.0505 & 0 & 0.1707 & 0.0147 & 0 & 0.0107 & 0.2550 & 1.626745 \\
\hline 16 & 2.9484 & 4.4226 & 2.9484 & 0.3942 & 3.5703 & 0.0613 & 0.0135 & 0.0000 & 0.0059 & 0.1331 & 1.293596 \\
\hline 17 & 2.9484 & 4.4226 & 2.9484 & 0.0342 & 2.8117 & 12.7116 & 0.0273 & 0.0203 & 0.0062 & 0.0723 & 1.37666 \\
\hline 18 & 2.9484 & 4.4226 & 2.9484 & 1.1910 & 4.6865 & 0.0459 & 0.0106 & 0 & 0.0055 & 0.2295 & 1.33783 \\
\hline 19 & 4.4226 & 1.4714 & 2.9484 & 1.5795 & 1.5004 & 0.0426 & 0.0203 & 0.0108 & 0.0205 & 0.1239 & 1.602207 \\
\hline 20 & 4.4226 & 1.4714 & 2.9484 & 15 & 0 & 0.0495 & 0.0102 & 0.0365 & 0.1770 & 0.1532 & 1.759485 \\
\hline 21 & 4.4226 & 1.4714 & 2.9484 & 4.6066 & 0.0925 & 0.0233 & 0.0101 & 0.0062 & 0.2219 & 0.3293 & 1.644378 \\
\hline 22 & 4.4226 & 2.9484 & 2.9484 & 15 & 0 & 0.0128 & 0.0125 & 0 & 0.3158 & 0.1083 & 1.677388 \\
\hline 23 & 4.4226 & 2.9484 & 2.9484 & 8.8191 & 1.6479 & 0.0231 & 0.0100 & 0.0033 & 0.0166 & 0.1530 & 1.719904 \\
\hline 24 & 4.4226 & 2.9484 & 2.9484 & 12.1325 & 6.7678 & 14.3080 & 0.0036 & 9.1681 & 0.0003 & 0.2815 & 0.963317 \\
\hline 25 & 4.4226 & 4.4226 & 2.9484 & 5.9174 & 0.1286 & 0.0272 & 0.0071 & 0.0226 & 0.0213 & 0.2420 & 1.208793 \\
\hline 26 & 4.4226 & 4.4226 & 2.9484 & 0.0230 & 0 & 0.0573 & 0.0147 & 0 & 0.0073 & 0.1164 & 1.980805 \\
\hline 27 & 4.4226 & 4.4226 & 2.9484 & 10.3146 & 0.6149 & 0.0414 & 0.0130 & 0.0261 & 0.0013 & 0.1213 & 2.482569 \\
\hline
\end{tabular}


$k_{31}=0.0238 \mathrm{moll}^{-1} \mathrm{~min}^{-1}, k_{41}=0.0021 \mathrm{moll}^{-1} \mathrm{~min}^{-1}$, and $k_{51}=0.0142 \mathrm{~mol} \mathrm{I}^{-1} \mathrm{~min}^{-1}$. The concentration of DHSA obtained from this simulation was $1.954907 \mathrm{moll}^{-1}$.

\subsection{Optimisation of DHSA through Taguchi method}

To determine the optimum reaction conditions for the production of DHSA, the Taguchi method was used, as presented in Table 3. Signal to noise $(\mathrm{S} / \mathrm{N})$ ratio is an analytical medium used to evaluate the most influential level of each factor that contributes to the optimum response value. L-27 orthogonal array with four factors and three levels for each factor was selected. The Taguchi orthogonal array experimental design is presented in Table 3, where the estimated concentration of DHSA was obtained from the simulation.

Table 3 - Taguchi orthogonal array experimental design for DHSA

\begin{tabular}{|c|c|c|c|c|c|}
\hline \multirow[b]{2}{*}{ Run } & \multicolumn{4}{|c|}{ Reaction parameters and their levels } & \multirow{2}{*}{$\begin{array}{c}\text { DHSA estimated } \\
\text { concentration } / \\
\text { moll }^{-1}\end{array}$} \\
\hline & $\begin{array}{c}\text { Temperature } \\
/{ }^{\circ} \mathrm{C}\end{array}$ & $\mathrm{FA} / \mathrm{OA}$ & $\mathrm{H}_{2} \mathrm{O}_{2} / \mathrm{OA}$ & $\begin{array}{l}\text { Agitation } \\
\text { speed / } \\
\text { rpm }\end{array}$ & \\
\hline 1 & 1 & 1 & 1 & 1 & 0.733307 \\
\hline 2 & 1 & 1 & 1 & 1 & 0.700095 \\
\hline 3 & 1 & 1 & 1 & 1 & 1.017948 \\
\hline 4 & 1 & 2 & 2 & 2 & 0.404717 \\
\hline 5 & 1 & 2 & 2 & 2 & 0.626330 \\
\hline 6 & 1 & 2 & 2 & 2 & 0.482747 \\
\hline 7 & 1 & 3 & 3 & 3 & 0.467893 \\
\hline 8 & 1 & 3 & 3 & 3 & 0.469234 \\
\hline 9 & 1 & 3 & 3 & 3 & 0.360169 \\
\hline 10 & 2 & 1 & 2 & 3 & 1.583085 \\
\hline 11 & 2 & 1 & 2 & 3 & 1.954907 \\
\hline 12 & 2 & 1 & 2 & 3 & 1.603342 \\
\hline 13 & 2 & 2 & 3 & 1 & 1.592831 \\
\hline 14 & 2 & 2 & 3 & 1 & 1.941024 \\
\hline 15 & 2 & 2 & 3 & 1 & 1.626745 \\
\hline 16 & 2 & 3 & 1 & 2 & 1.293596 \\
\hline 17 & 2 & 3 & 1 & 2 & 1.376660 \\
\hline 18 & 2 & 3 & 1 & 2 & 1.337830 \\
\hline 19 & 3 & 1 & 3 & 2 & 1.602207 \\
\hline 20 & 3 & 1 & 3 & 2 & 1.759485 \\
\hline 21 & 3 & 1 & 3 & 2 & 1.644378 \\
\hline 22 & 3 & 2 & 1 & 3 & 1.677388 \\
\hline 23 & 3 & 2 & 1 & 3 & 1.719904 \\
\hline 24 & 3 & 2 & 1 & 3 & 0.963317 \\
\hline 25 & 3 & 3 & 2 & 1 & 1.208793 \\
\hline 26 & 3 & 3 & 2 & 1 & 1.980805 \\
\hline 27 & 3 & 3 & 2 & 1 & 2.482569 \\
\hline
\end{tabular}

The "larger-the-better" S/N ratio indicated better performances regardless of the performance characteristics. According to the previous research, ${ }^{6}$ the optimum level for all parameters would be the level with the greatest $\mathrm{S} / \mathrm{N}$ ratio. The 27 experimental runs based on Taguchi method suggested that the optimum DHSA was obtained at $\mathrm{H}_{2} \mathrm{O}_{2} / \mathrm{OA}$ unsaturation molar ratio of $1: 1$ (level 2), FA/OA unsaturation molar ratio $0.5: 1$ (level 1), temperature of $35{ }^{\circ} \mathrm{C}$ (level 1), and agitation speed of $100 \mathrm{rpm}$ (level 1). These results were plotted for each parameter in Fig. 2.

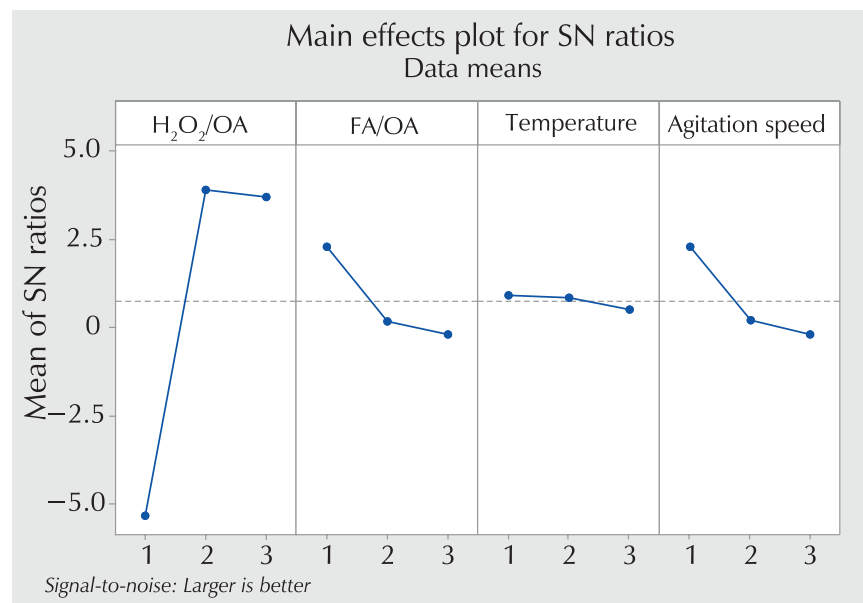

Fig. $2-\mathrm{S} / \mathrm{N}$ Ratio for each level parameter affecting the DHSA yield

\section{Conclusion}

By developing the kinetic model of palm oil, it was found that the kinetic parameters were $k_{11}=6.6442 \mathrm{~mol} \mathrm{I}^{-1} \mathrm{~min}^{-1}$, $k_{12}=11.0185 \mathrm{moll}^{-1} \mathrm{~min}^{-1}, k_{21}=0.1026 \mathrm{moll}^{-1} \mathrm{~min}^{-1}$ for epoxidation process, and $k_{31}=0.0238 \mathrm{moll}^{-1} \mathrm{~min}^{-1}$, $k_{41}=0.0021 \mathrm{moll}^{-1} \mathrm{~min}^{-1}, k_{51}=0.0142 \mathrm{moll}^{-1} \mathrm{~min}^{-1}$ in a degradation process. Furthermore, each of the reactions involved in the epoxidation and degradation process was successfully simulated in MATLAB. The minimum error for the simulation was about $0.0937 \%$. From the generated simulation, the data of DHSA yield in the reaction was obtained. Based on the chemical equation, the reactant will be used up, while the value of the concentration for the product will increase. Thus, the kinetic model was valid and the objective was achieved. The optimisation of DHSA yield was studied by the Taguchi method. The method resulted in the optimum value for producing DHSA based on the factors that had been decided, which were $\mathrm{H}_{2} \mathrm{O}_{2} / \mathrm{OA}$ unsaturation molar ratio of $1: 1$ (level 2), FA/OA unsaturation molar ratio $0.5: 1$ (level 1), temperature of $35^{\circ} \mathrm{C}$ (level 1), and agitation speed of $100 \mathrm{rpm}$ (level 1). From these values, the optimised value of DHSA can be achieved. 


\section{List of abbreviations}

$\begin{array}{ll}\text { DEG } 1 & \text { - degradation } 1 \\ \text { DEG } 2 & \text { - degradation } 2 \\ \text { DHSA } & \text { - dihydroxystearic acid } \\ \text { FA } & \text { - formic acid } \\ \text { OA } & \text { - oleic acid } \\ \text { EPO } & \text { - epoxidized palm oil } \\ \text { PFA } & \text { - performic acid } \\ \text { EPOXY } & \text { - epoxidized oil } \\ \text { S/N } & \text { - signal to noise }\end{array}$

\section{References}

\section{Literatura}

1. "The Oil Palm Tree." [Online]. Available: https://www. palmoilhealth.org/what-is-palm-oil/the-oil-palm-tree/. [ACcessed: 25-Nov-2018].

2. M. J. Jalil, S. K. Jamaludin, A. Rafizan, M. Daud, Degradation Oxirane Ring Kinetics of Epoxidized Palm Kernel Oil-Based Crude Oleic Acid, Ch\&ChT 12 (3) (2018) 296-299, doi: https://doi.org/10.23939/chcht12.03.296.

3. R. Guo, C. Ma, S. Sun, Kinetic Study on Oxirane Cleavage of Epoxidized Palm Oil, JAOCS 88 (4) (2011) 517-521, doi: https://doi.org/10.1007/s11746-010-1697-4.

4. C. Y. May, K. Nesaretnam, Highlight Article Research advancements in palm oil nutrition, Eur. J. Lipid Sci. Technol. 116 (10) (2014) 1301-1315, doi: https://doi.org/10.1002/ ejlt.201400076.

5. Q. Ren, J. Pan, J. Zhou, Y. Na, C. Chen, W. Li, Synthesis and Tribological Studies of Branched Alcohol Derived Epoxidized Synthesis and Tribological Studies of Branched Alcohol Derived Epoxidized Biodiesel, Materials 8 (10) (2015) 6623-6632, doi: https://doi.org/10.3390/ma8105326.

6. R. Ismail, R. Awang, A. H. Hazimah, Palm dihydroxystearic acid (DHSA): A multifunctional ingredient for various applications, J. Oil Palm Res. 27 (3) (2015) 195-211, url: http://jopr.mpob.gov.my/wp-content/uploads/2015/09/joprv27sept-rosnah1.pdf.

7. G. Koay, A. L. Chuah, R. Yunus, P. Siwayanan, Crystallization of dihydroxystearic acid (DHSA) produced from commercial grade palm oil based crude oleic acid employing isopropyl alcohol as solvent, Int. J. Eng. Technol. 3 (1) (2006) 115-124.

8. K. S. Prasad, C. S. Rao, D. N. Rao, Study on Factors Effecting Weld Pool Geometry of Pulsed Current Micro Plasma Arc Welded AISI 304L Austenitic Stainless Steel Sheets Using Statistical Approach, J. Miner. Mater. Charact. Eng. 11 (8) (2012)790-799, doi: https://doi.org/10.4236/jmmce.2012.118068.

9. S. Athreya, Y. D. Venkatesh, Application of Taguchi Method for Optimization of Process Parameters in Improving the Surface Roughness of Lathe Facing Operation, IRJES 1 (3) (2012) 13-19, url: http://irjes.com/Papers/vol1-issue3/Version\%201/C131319.pdf.

10. A. Martínez-Vargas, Optimizing grade-control drillhole spacing with conditional simulation, 33 (2017) 1-12, url: http:// scielo.sld.cu/pdf/mg/v33n1/mg01117.pdf.

11. D. B. Wijayasekara, Minimum Agitation Speed for Solid Suspension and Mixing Time in a Torispherical-Bottomed Pharmaceutical Stirred Tank Under Different Baffling Conditions, MSc Thesis, p. 125, 2007. 


\section{SAŽETAK}

\section{Dihidroksistearinska kiselina (DHSA) visokog prinosa temeljena na kinetičkom modelu iz epoksidiranog palmina ulja}

Mohd Jumain Jalil, a* Khairul Azhar Kamal, a Aliff Farhan Bin Mohd Yamin, ${ }^{a}$ Intan Suhada Azmi, ${ }^{\mathrm{b}}$ Mohamad Hasni Hassan, ${ }^{a}$ Abdul Rani Hidayu ${ }^{\mathrm{b}}$ i Kamariah Noor Ismail ${ }^{\mathrm{c}}$

Posljednjih godina studije povezane s epoksidacijom masnih kiselina izazvale su veliko zanimanje zbog sve veće potražnje za ekološki prihvatljivim epoksidima dobivenim iz biljnih ulja. Iz reakcije epoksidacije dolazi do nuspojave koja uključuje epoksid i vodu. Tom reakcijom nastaje nusproizvod - dihidroksistearinska kiselina (DHSA). DHSA jedan je od kemijskih prekursora u proizvodnji kozmetičkih proizvoda. Stoga je razvijen kinetički model za određivanje optimiranog procesa epoksidacije i koncentracije DHSA, gdje je identificirana svaka od reakcija. Dobiveni parametri kinetičke brzine, $k$ bili su: $k_{11}=6,6442, k_{12}=11,0185, k_{21}=0,1026$ za epoksidacijsku palmino-oleinsku kiselinu i $k_{41}=0,0021, k_{51}=0,0142$ u procesu razgradnje. Minimalna pogreška simulacije bila je 0,0937. Uz to, optimizacija prinosa DHSA provedena je Taguchijevom metodom, a dobiveni optimalni uvjeti su molarni omjer nezasićenja $\mathrm{H}_{2} \mathrm{O}_{2}$ /oleinske kiseline - OA $1: 1$ (razina 2), molarni omjer nezasićenja mravlje kiseline - FA/OA 0,5:1 (razina 1), temperatura $35{ }^{\circ} \mathrm{C}$ (razina 1) i brzina miješanja $100 \mathrm{o} \mathrm{min}^{-1}$ (razina 1). Pod tim se uvjetima može postići visok prinos DHSA.

\section{Ključne riječi}

Epoksidacija, kinetika, MATLAB, DHSA, Taguchi

${ }^{a}$ Faculty of Chemical Engineering, Universiti Teknologi MARA Cawangan Pulau Pinang,

Kampus Permatang Puah, 13500 Permatang Pauh, Pulau Pinang

${ }^{\mathrm{b}}$ Faculty of Chemical Engineering, Universiti Teknologi Mara Cawangan Johor Kampus Pasir Gudang, 81750 Masai, Johor

c Faculty of Chemical Engineering, Universiti Teknologi MARA, 40450 Shah Alam, Selangor
Izvorni znanstveni rad Prispjelo 30. ožujka 2020. Prihvaćeno 27. srpnja 2020. 